\title{
e-Phaïstos
}

e-Phaïstos

Revue d'histoire des techniques / Journal of the history

of technology

IV-2 | 2015

Patrimoines de l'eau

\section{The Palmeral of Elche: an urban irrigation landscape}

La palmeraie d'Elche: un paysage d'irrigation urbaine

\section{Mauricio Ballesteros Huesca}

\section{(2) OpenEdition}

Journals

Electronic version

URL: http://journals.openedition.org/ephaistos/742

DOI: $10.4000 /$ ephaistos.742

ISSN: 2552-0741

\section{Publisher}

IHMC - Institut d'histoire moderne et contemporaine (UMR 8066)

\section{Printed version}

Date of publication: 1 October 2015

Number of pages: $36-48$

ISSN: 2262-7340

Electronic reference

Mauricio Ballesteros Huesca, « The Palmeral of Elche: an urban irrigation landscape », e-Phaïstos

[Online], IV-2 | 2015, Online since 28 November 2016, connection on 01 May 2019. URL : http:// journals.openedition.org/ephaistos/742 ; DOI : 10.4000/ephaistos.742 


\section{The Palmeral of Elche : an urban irrigation landscape.}

\section{Introduction}

The Palmeral of Elche is an irrigation landscape created in the medieval Muslim Spain, linked with the founding of Elche in the tenth century. Thus, the application of well-known techniques in the Arab world enabled the development of an irrigated agriculture in an environment with scarce water resources. The historic Palmeral, which comprises the oldest palm plantations around the town with the greatest cultural significance, survived the Christian conquest in the thirteenth century and has endured to this day, although it has lost its agricultural function and its area, affected by urban sprawl, has been reduced. This cultural landscape, result of the transfer of knowledge during the Islamic expansion, was inscribed on the UNESCO World Heritage List in 2000.

With the aim of providing an overall view about the main features of this landscape created in AlAndalus times and its current situation, this paper is structured as follows: after this introduction, the second section defines the Palmeral and its functioning. In the third section we will focus on the irrigation system, the backbone of this agrosystem. Finally, in the fourth section we will address the protection and enhancement issues that have defined its recent evolution.

\author{
Mauricio Ballesteros Huesca \\ PhD student. University of Alicante. \\ University of Padua
}

\begin{abstract}
An oasis in Al-Andalus
The Palmeral is an agrosystem developed as an oasis $^{1}$. An oasis is the result of traditional techniques that were applied in the Arabian world for ages to help man to survive in a hostile environment. Thus, man can break the cycle of aridity locally by means of actions that increase humidity and soil fertility, making the most of the scarce resources around. The planting of date palm trees, the way plots are arranged and the use of accurate techniques to get and manage water are the result of a well studied plan, which creates a microclimate where crops can be grown ${ }^{2}$.

The origins of this agrosystem are related to the founding of the Islamic town of Elche in the second half of the tenth century, during the Al-Andalus age3. This area has an arid soil and an important hydrological deficit: rainfalls are scarce and irregular, like the flow of the Vinalopó River, which carries brackish water ${ }^{4}$. Thus, what today is known as the historic Palmeral, was a large irrigated area organized on the outskirts of the Islamic town on the left bank of the river, where the water was brought by a complex system of canals from the river to the crop5.

The Islamic town was the planner and organizing hub of the irrigated area, and there was a strong link between them ${ }^{6}$. The field provided
\end{abstract}


nourishment and farm products for the population and the local markets.7 Moreover, the irrigation system crossed the town, conditioning its design. It supplied baths and markets with water ${ }^{8}$. In addition, these canals favoured the setting up of small industries over time such as oil and soap producers, traditional activities in Elche since medieval times 9.

The huerto is the traditional agricultural unit of the Palmeral. It is the place where intensive practices of irrigated agriculture are developed. The whole irrigated area defined by the group of huertos is known as the huerta ${ }^{10}$. The huerto is composed of elements closely interlinked: the alignment of the palm trees, the plots, the irrigation system and the associated crop. Thus, palm trees are planted in line according to a grid-pattern, usually along the irrigation canals, delimiting plots. This way, the palm trees form a wall against the wind and produce shade over the plots, reducing the evaporation and generating soil suitable to grow associated crops such as forage plants, cereal (corn, wheat, barley, alfalfa) or medium-sized trees like pomegranate trees. In addition to these elements, the traditional physical structure of the huerto comprised some constructions, such as houses, perimeter walls or water tanks and paths ${ }^{11}$.

The planned design of the huertos pursues an optimal use of the scarce resources. The productive function of the agricultural system is maximized by the contiguity of these palm plantations and the spatial regularity of the plots ${ }^{12}$, as they favour a more efficient and controllable distribution of the irrigation water ${ }^{13}$. Thus, the historic Palmeral was characterized by the high concentration of huertos constituted in its traditional conception around the medieval town, where an intensive irrigated agriculture was organized.

The date palm tree is characterized by its resistance to drought and brackish water. However, the interest in its cultivation goes beyond its function developed in this microclimate. In addition to producing dates, it has been used for religious purposes: the white palm, obtained after the application of traditional techniques to the palm tree, plays a major role in the Palm Sunday procession at Easter. Furthermore, it provides materials like wood and fibres, which have been used as construction elements. It is also worth mentioning the high ornamental value of this plant ${ }^{14}$.

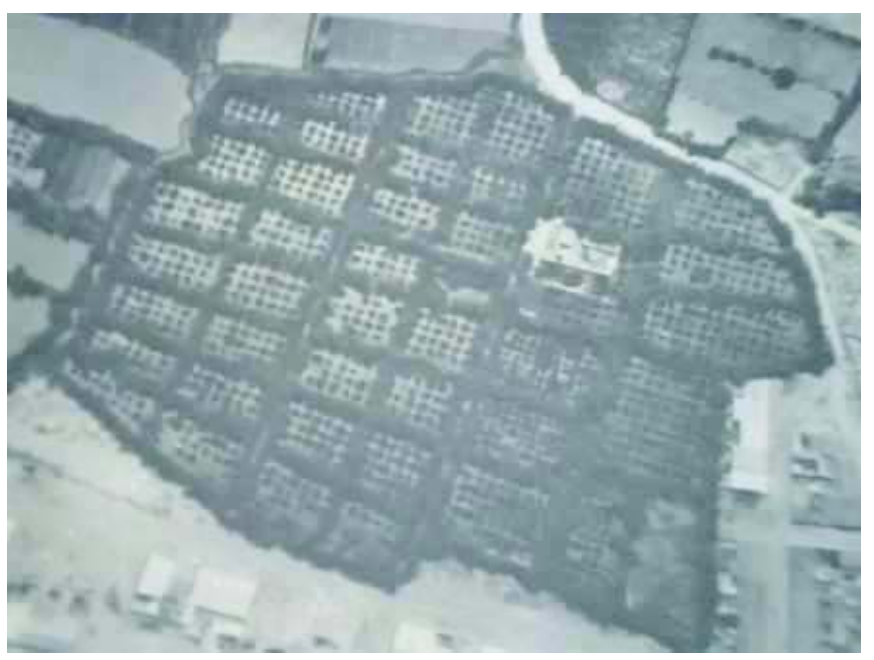

Figure 1 : Huerto with agricultural function.

Source : Archivo Histórico Municipal de Elche (AHME).

Without a doubt, the network of ditches and the accurate organization of the irrigation made possible the creation and maintenance of this agrosystem. The main features of this historical irrigation system are addressed below.

\section{The irrigation system}

The irrigation system is essential for this agrosystem: an extensive network of canals defines the crop areas, leaving its mark on the landscape. The key element in this system is the Acequia Mayor ${ }^{15}$, which has branches. These branches are divided into minor canals that take the water to the 


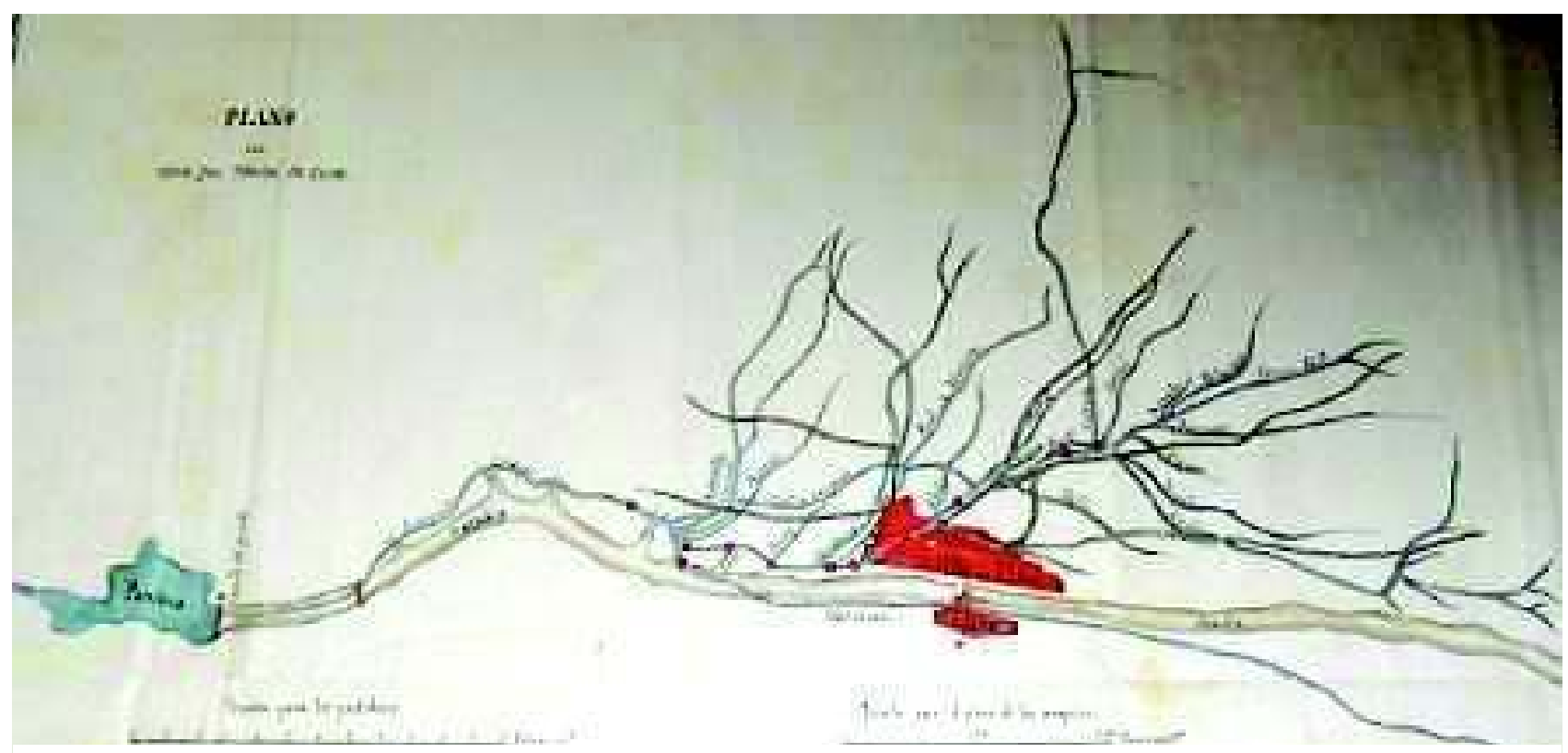

Figure 2 : The irrigation system. Source : AHME.

plots $^{16}$. It is also remarkable how the irrigation is organized, being focused on the maximum use of the scarce water resources.

After the Christian conquest in the thirteenth century, the Islamic town of Elche and its field were occupied by Christian settlers and the Muslims were expelled to the right side of the Vinalopó River. From that century onwards there is evidence of the duality of the system. On the one hand, the Acequia Mayor kept irrigating the land formerly occupied by the Muslims and since then by the Christians. On the other hand, the Acequia de Marchena, which was apparently a branch of the stem canal of the Acequia Mayor, irrigated the Islamic crops on the other side of the river ${ }^{17}$.

The first documentary evidence that sheds a light on the functioning of this Al-Andalus irrigation system is subsequent to the conquest. However, the way the water was distributed during the Christian age seems to be based on the previously existing model in the Muslim period ${ }^{18}$. Let us approach the main features of this system dominated by the Acequia Mayor, which has shaped the landscape in such a decisive way.

\section{The network of irrigation ditches}

In the historical design of the network of ditches, a 4 kilometre stretch can be identified as the stem canal of the Acequia Mayor ${ }^{19}$. The main function of this first stretch is to carry water taken from the Vinalopó River to the irrigation areas, so it has no branches. This section finishes before reaching two fixed partidores ${ }^{20}$ located in the north of the town, where the flow is divided. The partidor de Albinella diverts water for urban supply. The partidor de Marchena is the starting point of the Acequia de Marchena and diverts water to the right bank of the river. Then, the Acequia Mayor crosses the town and goes southward. Along this second stretch, 
there are over 20 branches. According to Guinot and Selma, the Acequia Mayor finishes in a partidor located two kilometres south of the town, which divides the main canal in two minor ditches ${ }^{21}$.

Diverse elements that favour the proper functioning of the system can be found along the Acequia Mayor. Among them, the mobile partidores are highly peculiar. They are made of wood and stone and are located at the sources of the branches, right at the point where they take water from the Acequia Mayor. Due to their mobility, the amount of water transferred can be controlled ${ }^{22}$.

In addition, water mills were built on the main canal, which were mainly destined to flour production. Their existence has been documented since the early Christian period (XIV century). However, some mills were probably built in Muslim times. After some restructurings and activity changes, the emergence of the electric energy made them disappear in the course of the twentieth century ${ }^{23}$.

\section{The organization of the irrigation: proportionality, turns and zoning}

The traditional organization of the irrigation is characterized by three aspects: proportionality, turns and zoning. Thus, each irrigator would not receive a certain amount of water but a proportion of the flow carried by the main canal, common circumstance in the east of Al-Andalus. Moreover, the water was distributed by tandas (irrigation rounds). The tanda was the period of time within which each irrigator has an allotted time according to a predetermined sequence ${ }^{24}$. Additionally, the irrigation water seems to have been distributed according to a geographical scheme, as some areas were better supplied than others.

According to the documents from the Christian age, the flow running along the stem canal has been historically divided into 12 parts of water 25 .Two fixed partidores set the first flow divisions. The partidor de Albinella diverted 1 part for urban uses. The partidor de Marchena diverted 2 parts to the right bank of the river to water the Muslim irrigated area (huerta de los moros). The remaining 9 parts ran along the Acequia Mayor on the left bank to water the Christian irrigated area (huerta de los cristianos) ${ }^{26}$.

As for the Acequia Mayor, the list of water rights holders and the irrigation turns were collected in two documents: the Libro Mayor and the Libro $\mathrm{ChiCO}^{27}$. Irrigators would wait for their turn to receive the water according to the set schedule within 37.5 days, the duration of a tand $a^{28}$.

Considering the way the water is distributed in these documents, the irrigation system seems to be organized according to a geographic scheme. In that regard, the water was subject to a variable regime: huerto water and dula water, the latter being submitted to strict limitations ${ }^{29}$. This regime favoured the plots closer to the town rather than the distant ones. Thus, a first ring where intensive irrigated agriculture was practiced can be identified. It was formed by the huertos concentrated around the medieval town, irrigated by canals not subject to dula water. A second ring would be formed by the fields irrigated by dula water, located at points further away from the town and at the ends of the system, not being as well provided with hydrological resources as the first one ${ }^{30}$.

\section{Recent evolution of the historic Palmeral}

Throughout the twentieth century, the historic Palmeral was seriously damaged as a result of urban pressure and the abandonment of huertos, which lost their agricultural function. The extent of these attacks is variable. Some huertos totally disappeared due to palm tree uprooting or the lack of a minimum maintenance. In other cases, the alignment of palm trees was respected, but traditional elements were removed. Houses, social infrastructure and parks were built on these plots. 
Also, the development of railway and road infrastructures had a negative impact on them.

For decades, the issues surrounding the urban huertos were addressed from sectoral perspectives, without considering the complex nature of an irrigation landscape in an urban environment. The focus was on the palm tree instead of the whole agrosystem, and its agricultural nature was not recognised. Fortunately, since the end of the century, and, specially, after the declaration of an area of the urban Palmeral as a UNESCO World Heritage Site in 2000, this situation started to change. From that moment on, the recovery of its original identity has been a greater concern.

\section{Twentieth century. Abandonment of huertos and urban pressure}

Probably, the Palmeral surrounding the city reached its highest extension in the nineteenth century ${ }^{31}$. However, since the late part of that century and during the first decades of the twentieth century, the huertos started to suffer important attacks. These years were characterized by a lack of land to meet the needs of both the expanding footwear industry, which has played a key role in the local economy throughout the twentieth century, and the growing population $3^{2}$. Also, the diffusion of electric power allowed pumping water from the Segura River surplus, which had a higher quality than the water of the Vinalopó River. As a result, irrigated land extended throughout former dry fields in the countryside and new varieties with higher water requirements were planted. The competition from this new irrigated land increased the loss of economic value of the urban huertos as agricultural production units 33 . Thus, this situation contributed to the occupation, damage and destruction of huertos with industrial and housing purposes 34 . In addition, with the arrival of the railway in 1884, the historic Palmeral had been sectioned 35 .

It is during these years when the first legal actions to protect the Palmeral took place, after the concerns of a sector of the society of Elche headed by Pedro Ibarra, municipal archivist and prominent local figure. In this regard, a decree declared the conservation of the palm tree as a social interest in 1933. As a result, the cutting down of living palms, as well as other damaging actions against them were prohibited. Another decree concerned about its cultural importance declared the Palmeral as Jardín Artístico in 1943, which is the basis for its current classification as Bien de Interés Cultural in the category of Jardín Histórico ${ }^{36}$.

As a consequence of the Spanish Civil War (1936-1939) and the difficult post-war years, defined by hunger and scarcity of raw materials, the interest in cultivating these huertos increased, contributing, to some degree, to their protection and maintenance as agricultural land 37 .

The urban planning regulations promulgated by the Local Government between the fifties and the mid-eighties did not provide the suitable solution to protect the urban huertos, being a backward step from the decree of 1933. In fact, they favoured the use of their land for housing and social infrastructure, being detrimental to their agricultural function.

With the approval of new ordinances in 1951, detached houses were allowed to be built in the huertos, forming a sort of garden city 38 . The General Urban Development Plan of 1962 included these ordinances and permitted new uses in the urban huertos, like education and hospitality services or parks. It also adopted new regulations affecting two of them, in which palm trees could be replanted on a corner in order to build on the plots, breaking their alignment. These years, the sixties, were characterized by both the great development of the footwear industry and the significant growth of population in Elche. 39

The coming into force of new urban regulations in the early seventies produced the division of the urban Palmeral into various zones $4^{\circ}$. As a consequence, certain palm plantations were 


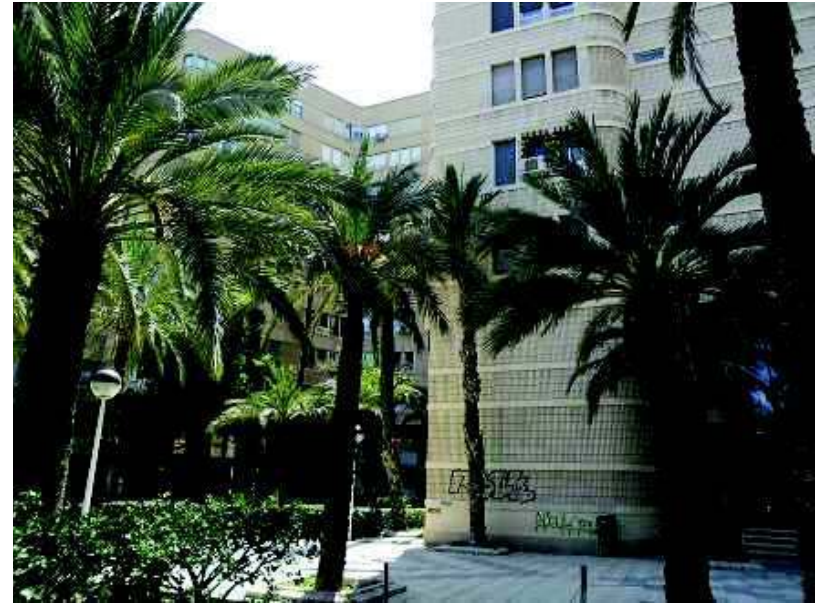

Figure 3 : Huertp occupied by a residential building.

classified as social huertos, which were allowed to house a diverse range of activities: artistic gardens; schools; health, sport and religious facilities; hotels, or houses. The aim was to use these former agricultural spaces for social infrastructure in order to meet the needs of a growing population living in an area with a high urban density. However, the inadequate distribution of these social huertos led to the fragmentation of the historic Palmeral. These regulations implied the urban invasion of the huertos, being greatly affected by the construction of public and private buildings ${ }^{41}$.

In 1986, the Regional Government promulgated the Law of the Tutelage and Protection of the Palmeral of Elche derogating the previous regulations, characterized by their sectoral nature. The aim of this new law still in force is to protect the date palm tree and its surroundings and to encourage its cultivation, safeguarding the historical and cultural values. It also determines the obligations to be fulfilled by the owners of huertos, groups of palm trees and dispersed palm trees of historic and cultural interest. In addition, a Board is created as the body responsible for the implementation of the corresponding regulations ${ }^{42}$.
However, some aspects of this law have been criticized, as it has not succeeded in maintaining the agricultural identity of the huertos. In that respect, Larrosa points out the ineffective performance of the Board, the lack of economic incentives for farmers to keep plantations affected by profitability loss and the absence of specific protection on the structural elements of the huertos 43 .

At that time, the City Council started to move into a more comprehensive management of the urban Palmeral. This new approach was reflected in the General Urban Development Plans of 1986 and, specially, 1998. Among the new measures 44 , it is worth mentioning the acquisition by the Local Government of non-transformed private huertos in order to turn them into public spaces. As a result, the main alteration undergone by the urban Palmeral during the last years of the twentieth century was the transformation of huertos into public parks and gardens 45 . However, this measure has not been totally consistent with the heritage protection, as some actions have affected their agricultural nature. In that regard, traditional elements of this agrosystem have been eliminated or modified, and others related to their new recreational function, like urban furniture, have

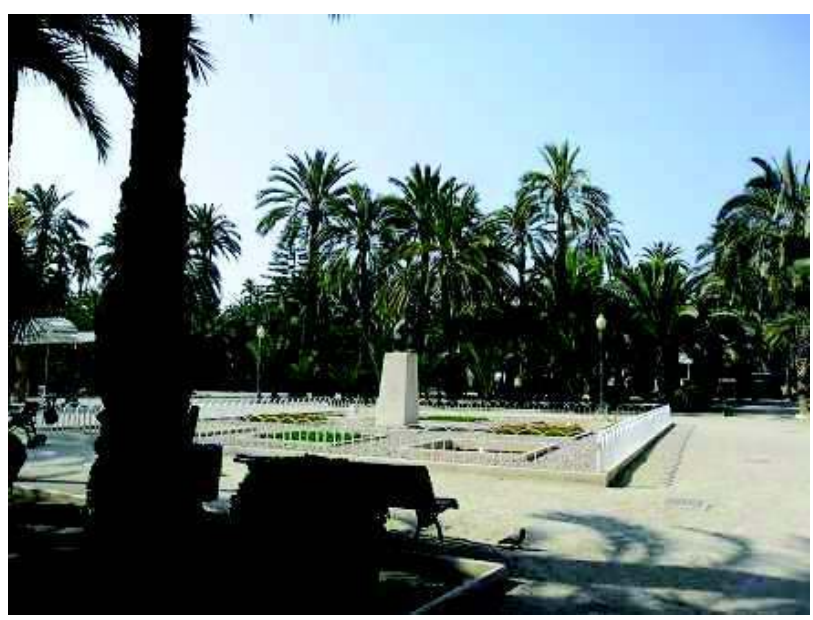

Figure 4 : Former huerto transformed into a park. 
been introduced. Since the recognition of an area of the Palmeral as a World Heritage Site in 2000, the concern for recovering their traditional identity has increased.

\section{Twenty-first century. World Heritage Site: a new scenario}

The Local Government decided in 1996 to prepare the candidacy of this agrosystem for its inscription on the UNESCO World Heritage List. After a first unsuccessful attempt, 67 urban huertos were registered as a World Heritage Site in 2000, covering an area of 144.20 ha $^{46}$. The UNESCO resolution highlighted that the Palmeral was originated by the transference of a characteristic cultural landscape from North Africa to Europe during the Islamic occupation of much of the Iberian Peninsula, which has survived to the present day. The ancient irrigation system, which is still functioning, was considered to be of special interest 47 . The designated area as World Heritage Site coincides with the location of the original palm tree plantations in the surroundings of the former Islamic town. The interconnection among these huertos, which creates a compact landscape, was also emphasized in the evaluation ${ }^{48}$. The recognition of the Palmeral as a World Heritage Site was a turning point. From that moment on, the recovery of its agricultural identity has become a greater concern for the City Council.

In 2008, the Local Government drew up the Special Protection Plan for the Palmeral of Elche, a technical document of urban nature. In January 2014, it was still pending final approval. This plan, unlike all previous regulations, approaches the huertos as a whole, forming a landscape unit, and its protection is contemplated according to the UNESCO criteria. It enhances the huertos with their original configuration as agricultural spaces and the elements of their physical structure, constructions and surrounding area are specifically protected. The main use value proposed is the contemplation and enjoyment of this landscape. It also intends to strengthen its tourist use 49 .

The enhancement of the Palmeral based on the recovery of its agricultural nature is a real challenge. However, tourism, favoured after the UNESCO recognition, may benefit the maintenance of this cultural landscape 50 . Thus, the recovery of its agricultural identity provides an experience of authenticity 51 , which is a highly appealing feature for tourists who treasure autochthonous traditions and the specific cultural identity of a place52. Moreover, the enjoyment of an agricultural landscape in an urban environment endows Elche with a high singularity53.

In doing so, a simplistic approach to tourism must be avoided. Actions that led to the transformation of certain huertos into tourist gardens in the past, losing much of their agricultural identity, should not be repeated. This is the case of the huertos that form the Jardin Huerto del Cura and the Municipal Park, which started to undergo changes in the decade of 1940. In spite of this, these two elements have contributed to create an attractive image of the city54.

Over the last few years, various municipal actions have been fixed on bringing this cultural landscape closer to visitors and fostering its original identity. In that regard, the tourist image of the city provided by the Local Government is focused on the agricultural landscape, as the promotional brand is "Elche, Mediterranean oasis"55. Also, a pedestrian route that covers historic huertos was set up in 2004. In 2005, the Museum of the Palmeral was opened in a historic huerto, reusing its traditional house. Visitors are shown the historical facts and the functioning of this agrosystem, as well as the traditional craft connected to it. In addition, a huerto with all the elements of its original structure is recreated $5^{6}$. In 2013, the former defensive tower located in the historic Huerto de los Vaillo was prepared as a viewpoint to contemplate the Palmeral. Moreover, it is also intended to promote a route that traces the most important elements of 
the irrigation system.

Currently, about two thirds of urban huertos are owned by the City Council. Their recovery and maintenance involve a significant economic burden, which is mainly borne by the municipal authority. It has been suggested the development of certain activities in these spaces, conducted also by the private sector, which may be a factor to attract visitors and ensure the economic sustainability of this cultural landscape. This proposal, which is not free of controversy, must be consistent with the objective of enhancing the urban huertos in their original configuration as agricultural land. In this regard, the Special Protection Plan for the Palmeral proposes the allowance of provisional constructions destined to house tourist and leisure activities and others related to the spreading of the culture on this agrosystem, like interpretation centres, exhibitions, workshops on traditional craft or the sale of huerto products, provided they do not affect its physical structure 57 .

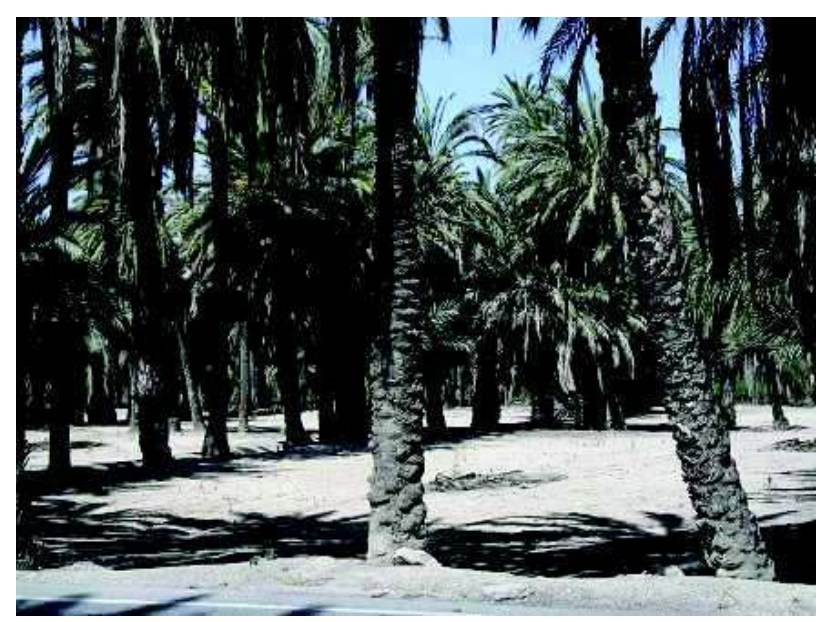

Figure 5 : Huerto with no agricultural function.
1 Agricultural ecosystems or agrosystems are anthropogenic systems: their origin and maintenance are related to human activity. SANS, Francisco X., «La diversidad de los agroecosistemas», Ecosistemas, 16, 2007, 1. p. 44.

2 LAUREANO Pietro, Atlas de agua. Los conocimientos tradicionales para combatir la desertificación, Barcelona, Ipogea, 2005, p.30-31; 144-146.

3 AZUAR Rafael, «Espacio hidráulico y ciudad islámica en el Vinalopó. La huerta de Elche», Agua y territorio. I Congreso de Estudios del Vinalopó, Petrel, Ayuntamiento de Petrel Ayuntamiento de Villena, 1998, p.13-15.

4 GIL Antonio, «El regadío de Elche», Estudios Geográficos, 1968, p. 529.

5 We have focused our study on the historic Palmeral, which nowadays is embedded in the city, and especially on that area of 144.20 ha recognized as a UNESCO World Heritage Site in 2000 due to its cultural and historical significance. However, it must be noted that the Palmeral also covers a large and disperse area outside the urban core. This rural Palmeral is younger and is still in agricultural production, unlike the historic one. The whole Palmeral has an approximate area of 441.20 ha. GRACIA Lina, Indicadores ambientales y paisajísticos del palmeral de Elche, Tesis doctoral. Elche, 2006, p.83,84.

6 This cultural landscape is understood as an agrosystem planned as an oasis and organized by the Muslim conquerors. However, the network of canals that divert water from the Vinalopó River to irrigate crops would have made use, to a greater or lesser extent, of some previous works dating from Roman times, which were improved. GOZALVEZ PEREZ Vicente, «La centuriato de Ilici», Estudios sobre centuriaciones romanas en España, Madrid, Universidad Autónoma de Madrid, 1974, p. 105-106.

7 GLICK Thomas, Regadío y sociedad en la Valencia medieval, Valencia, Biblioteca Valenciana, 2003, p.38-39. VERDÚ Carmina, El Palmeral de Elche. Un paisaje andalusí, SalobreñaGranada, Alhulia, 2011, p.119. AZUAR Rafael, «Espacio hidráulico..., op.cit., p.24.

8 Nowadays, one of these Arab baths can be visited in the basement of the Convent of La Merced. AZUAR Rafael, «Espacio hidráulico..., op.cit., p. 15, 24.

9GUINOT Enric and SELMA Sergi, Las acequias de Elche $y$ Crevillente, Valencia, Consellería d'Agricultura, Peixca i Alimentació, 2003, p. 147,148. 
${ }^{10}$ The Palmeral of Elche. A cultural landscape inherited from Allandalus. It is available on <http://www.cult.gva.es/palmeral/start.html >. Visited on 20.01.2014.

${ }^{11}$ GRACIA Lina, Indicadores..., op.cit., p.198; AYUNTAMIENTO DE ELCHE, Plan Especial de Protección del Palmeral. Tipología de los huertos de palmeras, 2013, p.2.

${ }^{12}$ The average size of the plots in the historic huertos is similar to one tahúlla: $953 \mathrm{~m}^{2}$. AYUNTAMIENTO DE ELCHE, Plan Especial de Protección del Palmeral. Tipología.., op.cit. , p.3.

${ }^{13}$ GRACIA Lina, Indicadores..., op. cit., p.21

14 AGULLÓ Miguel, GALIANA Carlos, La palmera datilera. Cultivo y aprovechamiento, Alicante, Instituto de Estudios Alicantinos, 1983, p. 201-233.

15 The Spanish word acequia comes from the Arabic language. It defines an irrigation ditch.

${ }^{16}$ VERDÚ Carmina, El Palmeral..., op.cit., p.46.

17 It is difficult to know whether the Acequia de Marchena existed on the original design of the system or it was an extension built later. Its peculiar water-taking mechanism, its physical structure and its location could show that it was an innovation, probably result of the Christian conquest, intended to irrigate a new space. GUINOT Enric and SELMA Sergi, Las acequias..., op. cit., p. 30-31, 37.

${ }^{18}$ It can be deduced from documents relating to the distribution of land after the Christian conquest that the new settlers had to manage the irrigation water as previously Muslims did. IBARRA Pedro, Estudio acerca de la institución del riego de Elche y origen de sus aguas, Madrid, Establecimiento tipográfico de Jaime Ratés, 1914, p.88-89.

19 A reservoir was built in the seventeenth century on the riverbed of the Vinalopó River in order to ensure water supply during drought periods. JAẾN I URBAN Gaspar, D'aigua I obres hidraùliques a Elx, Alicante, Universidad de Alicante, 1999, p.21.

20 The partidor divides the flow running along the canal into two parts. It enables to divert a fraction of water.

${ }^{21}$ GUINOT Enric and SELMA Sergi, Las acequias de Elche $y$ Crevillente, Valencia, Consellería d'Agricultura, Peixca i Alimentació, 2003, p. 48.
${ }^{22}$ GUINOT Enric and SELMA Sergi, Las acequias..., op. cit., p.115-117.

23 GUINOT Enric and SELMA Sergi, Las acequias..., op. cit., p.157-16o.

${ }^{24}$ In hydraulic systems subject to a significant water scarcity, the volumetric proportionality was superimposed by a distribution regime by turns. GLICK Thomas, Regadío y sociedad..., op. cit., p.383.

25Arts.79-80 in Reglamento para el régimen y gobierno de la comunidad de propietarios de las aguas de la acequia mayor del pantano de Elche, Elche, 1912. These regulations on the management of the irrigation water are based on earlier regulations, dated in 1791 .

26 These parts are also called hilos, being defined in volumetric proportion and time terms. As for the Acequia Mayor, each hilo is one twelfth of its flow running for twelve hours. Art. 81in Reglamento para el régimen..., op. cit.

${ }_{27}$ The Libro Chico, which shows a less complicated distribution system than the Libro Mayor, is likely to be the result of an innovation organized on the irrigation system in Christian times. Partial reproduction of Claridad de la acequia written by Ortiz de Mendoza in 1589, in: IBARRA Pedro, Estudio ..., op cit., p.109 - 111. GUINOT Enric and SELMA Sergi, Las acequias..., op. cit., p.6o-61.

${ }^{28}$ Art. 88 in Reglamento para el régimen..., op. cit.

${ }^{29}$ The dula water was forced to irrigate certain areas, depending on a certain partidor and according to strict turns. Partial reproduction of Claridad de la acequia written by Ortiz de Mendoza in 1589, in: IBARRA Pedro, Estudio ..., op. cit., p.110, 111; Arts. 83, 84 in Reglamento...

3o MARTÍNEZ Luis P., «El valor patrimonial universal dels regadius històrics valencians: el Palmerar i la Séquia Major d'Elx», Tractat de l'aigua, 1, 2008, p.78.; AZUAR Rafael, «Espacio hidráulico...», op. cit., p. 25-26.

${ }^{31}$ JAÉN I URBAN Gaspar, Les palmeres del migjorn valencià, València, Consell Valencià de Cultura, Generalitat Valenciana, 1994, p.52, 55-56.

${ }^{2}$ GOZÁLVEZ PÉREZ Vicente, La ciudad de Elche. Estudio geográfico, Valencia, Universidad de Valencia, Departamento de Geografía, 1976, p.114-115. 
33 GUINOT Enric and SELMA Sergi, Las acequias..., op. cit., p.27; 43-45.

34 In fact, an important expanse of palm plantations, 127,00om², disappeared completely between 1890 and 1933. LARROSA José Antonio, «El Palmeral de Elche. Evolución reciente y función turística después de su declaración como Patrimonio de la Humanidad», Ciudad y territorio. Estudios Territoriales, XXXV (135), 2003a, p. 130, 136-140.

35 Industrial companies were interested in locating their facilities near the railway station. JAÉN I URBAN Gaspar, Guía de la arquitectura y el urbanismo en la ciudad de Elche, Elche, COACV, Generalitat Valenciana, Ayuntamiento de Elche, 1989, p.152, 214 .

${ }^{36}$ These categories can be literally translated as follows: Jardín Artístico (Artistic Garden); Bien de Interés Cultural (Heritage of Cultural Interest) and Jardín Histórico (Historic Garden). Decree of the 8th of March of 1933 . Ministry of Agriculture, Industry and Commerce. Decree of the 27th of July of 1943. Ministry of National Education. CREMADES Vicente, " Protección y tutela normativa de "el palmeral de Elche"», Revista de Sociales y Jurídicas, 1, 2009, 4, p.89-95.

37 SEVILLA Martín, Crecimiento y urbanización. Elche 19601980, Valencia, Universidad de Alicante, Ayuntamiento de Elche, p. 195 .

38 SEVILLA Martín, Crecimiento y urbanización ..., op.cit., p.197.

39 AYUNTAMIENTO DE ELCHE, Plan Especial de Protección del Palmeral. Memoria informativa, 2013, p.14; SEVILLA Martín, Crecimiento y urbanización ..., op.cit., p.198.

40 These measures emanated from the Special Ordination Plan of the Palmerales of Elche of 1972, included in the General Urban Development Plan of 1973. It derogated the ordinances of 1951.

${ }^{41}$ According to Larrosa, an area of $329,495 \mathrm{~m}^{2}$ in the urban Palmeral was affected by the construction of public and private buildings between 1962 and 1986. LARROSA José Antonio, «El Palmeral de Elche. Evolución...»,op. cit., p. 141, 143-145, 148; SEVILLA Martín, Crecimiento y urbanización..., op.cit., p.199204.

${ }^{42}$ Law 1/1986, of May 9, which regulates the tutelage of the Palmeral of Elche; Diario Oficial de la Generalitat Valenciana (DOGV) of May 14, 1986, no. 376. Decree 133/1986, of November 10, which develops that law; $D O G V$ of December 1, 1986, no. 477.
43 LARROSA José Antonio, «El Palmeral de Elche. Evolución...»,op. cit., p.146.

44 The municipal actions included the establishment of financial support and agreements with huerto owners so that the Council could assume its basic maintenance. Also, a research and development centre on the date palm tree, the Phoenix Station, was set up in 1991. SAGASTA Julio and PINEDA Enrique, «La gestión del Palmeral de Elche», BARCIELA C., LÓPEZ M.I., MELGAREJO J. (eds.), Los bienes culturales y su aportación al desarrollo sostenible, San Vicente del Raspeig, Universidad de Alicante, 2012, p.591-601.

45 Between the mid-eighties and the mid-nineties, the Palmeral suffered a decline period. The surviving urban huertos with agricultural functions were abandoned due to their loss of profitability, and several palm trees were uprooted to be sold as ornamental plants. Between 1986 and 2000, 100,738 $\mathrm{m}^{2}$ of the urban Palmeral were transformed into park land, and 59,214 $\mathrm{m}^{2}$ were affected by the construction of private buildings. LARROSA José Antonio, «El Palmeral de Elche. Evolución...»,op. cit., p.147, 148.

${ }^{46}$ UNESCO defined a buffer zone protection around these 67 huertos of 224.5 ha. Nomination documentation: The Palmeral of Elche: a cultural landscape inherited from Al-Andalus. A revised nomination, p.1-30. It is available on< http://whc.unesco.org/uploads/nominations/930.pdf> Visited on 20.01.2014.

47 UNESCO, Convention concerning the protection of the World Cultural and Natural Heritage. World Heritage Committee, XXIV Session, 2001, p.48. It is available on $<$ http://whc.unesco.org/archive/2000/whc-00-conf20421e.pdf $>$. Visited on 20.01.2014.

${ }^{48}$ ICOMOS, Elche (Spain). No 93o. Identificación. Nomination: The Palmeral of Elche: A cultural Landscape Inherited from AlAndalus., 2000, p.137-139. It is available on $<$ http://whc.unesco.org/archive/advisory body evaluation/930 .pdf $>$. Visited on 20.01.2014.

49 The Special Plan of Protection of the Palmeral was originally drafted in 2008 and amended in 2013. AYUNTAMIENTO DE ELCHE, Plan Especial de Protección del Palmeral. Memoria...,op. cit.,p.1-3. 
${ }^{50}$ LARROSA José Antonio, «El palmeral de Elche: patrimonio, gestión y turismo», Investigaciones Geográficas, 30, 2003b, p.94.

${ }^{51}$ NURYANTI Wiendu, «Heritage and postmodern tourism», Annals of Tourism Research, 23, 1996, 2,p.250.

${ }^{2}$ Elche has an important endowment of cultural resources, which is mainly based on its two World Heritage distinctions: the Palmeral and the Misteri d'Elx. The latter is a sacred musical drama dating from the Middle Ages which is performed inside the Basilica of Santa Maria. It was proclaimed as a Masterpiece of Oral and Intangible Heritage of Humanity by UNESCO in 2001.

53 LARROSA José Antonio, MARTÍNEZ Antonio and AMAT Javier, «El palmeral de Elche. Patrimonio, identidad local e imagen turística», IVARS J.A. and VERA, J.F., Espacios turísticos: mercantilización, paisaje e identidad, San Vicente del Raspeig, Universidad de Alicante e Instituto Universitario de Investigaciones Turísticas, 2008, p 271. LARROSA José Antonio, «El palmeral de Elche. Patrimonio, gestión...», op.cit., p.95.

54 LARROSA José Antonio, MARTÍNEZ Antonio and AMAT Javier, «El palmeral ..., op. cit., ;JAÉN I URBAN Gaspar, Guía de la arquitectura..., op.cit., p. 222-239; 344-357

$55<$ http://www.visitelche.com $>$.Visited on 20.01.2014.

${ }^{56}$ In 2013, the Museum of the Palmeral received 9,861 visitors.

57 AYUNTAMIENTO DE ELCHE, Plan Especial de Protección del Palmeral. Normativa, 2013, p.20. 


\section{Bibliography}

AGULLÓ Miguel, GALIANA Carlos, La palmera datilera. Cultivo y aprovechamiento, Alicante, Instituto de Estudios Alicantinos, 1983.

AZUAR Rafael, «Espacio hidráulico y ciudad islámica en el Vinalopó. La huerta de Elche», Agua y territorio. I Congreso de Estudios del Vinalopó, Petrel, Ayuntamiento de Petrel Ayuntamiento de Villena, 1998, p.11-31.

CREMADES Vicente, «Protección y tutela normativa de "el palmeral de Elche"», Revista de Sociales y Jurídicas, 1, 2009,4, p.82-109.

GIL Antonio, «El regadío de Elche», Estudios Geográficos, 1968, p. 527-574.

GLICK Thomas, Regadío y sociedad en la Valencia medieval, Valencia, Biblioteca Valenciana, 2003.

GOZÁLVEZ PÉREZ Vicente, «La centuriato de Ilici», Estudios sobre Centuriaciones en España, Madrid, Universidad Autónoma de Madrid, 1974.

GOZÁLVEZ PÉREZ Vicente, La ciudad de Elche. Estudio geográfico, Valencia, Universidad de Valencia, Departamento de Geografía, 1976.

GRACIA Lina, Indicadores ambientales $y$ paisajísticos del palmeral de Elche, doctoral thesis. Elche, 2006.

GUINOT Enric and SELMA Sergi, Las acequias de Elche y Crevillente, Valencia, Consellería d'Agricultura, Peixca i Alimentació, 2003.

IBARRA Pedro, Estudio acerca de la institución del riego de Elche y origen de sus aguas, Madrid, Establecimiento tipográfico de Jaime Ratés, 1914.

JAÉN I URBAN Gaspar, Guía de la arquitectura y el urbanismo en la ciudad de Elche, Elche, COACV, Generalitat Valenciana, Ayuntamiento de Elche, 1989.
JAÉN I URBAN Gaspar, Les palmeres del migjorn valencià, València, Consell Valencià de Cultura, Generalitat Valenciana, 1994.

JAÉN I URBAN Gaspar, D’aigua I obres hidraùliques a Elx, Alicante, Universidad de Alicante, 1999.

LARROSA José Antonio, «El palmeral de Elche. Evolución reciente y función turística después de su declaración como Patrimonio de la Humanidad», Ciudad y territorio. Estudios Territoriales, XXXV (135), 2003a, p. 127-154.

LARROSA José Antonio, «El palmeral de Elche: patrimonio, gestión y turismo", Investigaciones Geográficas, 30, 2003b, p.77-96.

LARROSA José Antonio, MARTÍNEZ Antonio and AMAT Javier, " El palmeral de Elche. Patrimonio, identidad local e imagen turística», IVARS J.A. and VERA, J.F., Espacios turísticos: mercantilización, paisaje e identidad, San Vicente del Raspeig, Universidad de Alicante e Instituto Universitario de Investigaciones Turísticas, 2008, p. 271.

LAUREANO, Pietro, Atlas de agua. Los conocimientos tradicionales para combatir la desertificación, Barcelona, Ipogea, 2005.

MARTINEZ Luis P., «El valor patrimonial universal dels regadius històrics valencians: el Palmerar i la Séquia Major d'Elx», Tractat de l'aigua, 1, 2008, p.72-82.

NURYANTI Wiendu, «Heritage and postmodern tourism», Annals of Tourism Research, 23, 1996, 2, p. 249-260.

Reglamento para el régimen y gobierno de la comunidad de propietarios de las aguas de la acequia mayor del pantano de Elche, Elche, 1912.

SAGASTA Julio and PINEDA Enrique, "La gestión del Palmeral de Elche», BARCIELA C., LÓPEZ M.I., MELGAREJO J. (eds.), Los bienes 
culturales y su aportación al desarrollo sostenible, San Vicente del Raspeig, Universidad de Alicante, 2012, p.589-612.

SANS, Francisco X., «La diversidad de los agroecosistemas », Ecosistemas, 16, 2007, 1, p. 4449.

SEVILLA Martín, Crecimiento y urbanización. Elche 1960-1980, Valencia, Universidad de Alicante, Ayuntamiento de Elche, 1985.

VERDÚ Carmina, El Palmeral de Elche. Un paisaje andalusí, Salobreña-Granada, Alhulia, 2011. 